\title{
Psychophysical Motivational Effects of Music on Competitive Swimming
}

Authors' Contribution:

A - Study Design

B - Data Collection

C - Statistical Analysis

D - Data Interpretation

E - Manuscript Preparation

F - Literature Search

$\mathrm{G}$ - Funds Collection

\author{
Stefan Szczepan $^{1 \text { (A, B, C, D, E, F, G), Lesław Kulmatycki }}{ }^{2}$ (D) \\ ${ }^{1}$ University School of Physical Education in Wroclaw, Poland \\ Department of Swimming \\ ${ }^{2}$ University School of Physical Education in Wroclaw, Poland \\ Department of Health Promotion and Relaxation Techniques
}

Key words: psychophysical motivational effects, music, competitive swimming

\begin{tabular}{l|l} 
Abstract \\
Background:
\end{tabular}

Material/Methods: The employed research method relied on a laboratory experiment. The study included 8 subjects involved in swimming training. They were divided into two groups - control (C) and experimental (E) ones. The study consisted of three trials during which the subjects swam a distance of $50 \mathrm{~m}$ front crawl with maximum velocity. In the first trial neither of the groups had an independent variable. In trials two and three group $C$ swam the distance listening to white noise. Group $E$ received motivational music of choice (independent variable). Before and after the trials the subjects' motivation was assessed by means of the MOTO scale.

Results: The motivation level assessed by means of the MOTO scale revealed no statistically significant differences in the groups. The Mann-Whitney U Test showed no statistically significant differences between the study groups in terms of their times over 50 $m$.

Conclusions: Motivational music which the swimmers received when swimming had no impact on an increased level of the swimmers' motivation and swimming effectiveness.

Word count: 3,121

Tables: 1

Figures: 0

References: 40

Corresponding author:

Stefan Szczepan MSc

Department of Swimming University School of Physical Education, Wroclaw

al. I.J. Paderewskiego 35 (Swimming pool)

51-612 Wrockaw, Poland

Phone: +48713473404 Fax: +48713473450

E-mail: Stefan.Szczepan@awf.wroc.pl
Received: June 2012

Accepted: September 2012

Published: October 2012 


\section{Introduction}

For years music has been regarded as a beneficial element in the life of humans, an element influencing their health. It has been used for relaxation purposes and in medicine as part of therapeutic treatment [1]. At some point people began to appreciate its beneficial qualities in other areas as well, e.g. physical activity. Since music is believed to be able to motivate [2], spur into action [3], relax [4] and lower perceptions of effort, it has become increasingly used in sports and leisure activities. Its application in these areas has been facilitated by technological developments making it possible for music to accompany professional athletes or amateurs in their daily or occasional physical activities, while its benefits have been increasingly used to improve competitive performance or make physical leisure activities more pleasant. Music is a cure for the soul even for people commonly described as not very musical or completely unmusical, for amateurs and for competitive athletes. The present paper examines selected theoretical premises of the impact of music on the motor sphere of human life as well as practical implications resulting from a number of studies $[2,6]$.

The healing powers of music have been used since the earliest stages in the evolution of humanity. Pythagoras stressed its impact on mood changes [7]. The topic was analysed by ethnomusicologists' publications describing healing rituals [8].

In turn, Francois Delsarte pointed to the application of music as a movement stimulator [9], and a French educator Emil Jaques-Dalcroze pointed to the essence of experiencing music and stressed its value for a general development of individuals, noting his pupils' basic motor reactions to music [10]. As movement in music contains elements such as rhythm, tempo, dynamics, harmony and form - elements which are also present in physical movement - the discovery of the links between music and motor activity was inevitable and became the basis for their explanations. Rhythm was proclaimed to be the main factor determining the usefulness of music for motor activities [11]. Rhythm was responsible for the organisation of time in a piece of music, it introduced order and stimulated, with Dalcroze regarding it as the basis for motor activities [11]. It was also considered as a stimulating factor and as a response of the body to this stimulus [12], which is why it was treated as an important element of music. Tempo, i.e. the speed with which a piece is performed - slowly, moderately or fast - as well as agogical issues related to its successive changes, i.e. acceleration and slowing down [11], are also observed when motor tasks are performed. Dynamics were to describe the intensity of musical sounds. The shape of the melodic line influenced the choice of musical works, e.g. acting as relaxing or stimulating factors [13]. Harmony referred to consonances in chords and their links, signifying concordance of shapes. Harmonic changes occurring in music could influence emotional reactions [11]. The form of a musical work determined the choice of movements in its choreographic adaptation [11].

In subsequent years music treatment, already defined as music therapy, acquired a scientific basis, making its mark on healthcare centres. Music therapy was used in the treatment of stress and frustration, introducing emotional stability [14], entering the sphere of physical education in the subsequent stages of its development. Rhythmical and musical tasks were used as a musical education method during physical education classes in various forms to develop motor skills. Their influence usually made people's inner inhibitions, uncertainty and shyness disappear, and created an active interest as well as an atmosphere of joy and satisfaction [15]. Various original physical education methods were developed mainly on the basis of the melodic line of music. The Kniesses' rhythmic gymnastics involved a search for new forms of movement combined with rhythm and music [16]. Dance education according to Laban's method - influenced the learners' psychophysical development through dance and music [17]. Orff's pedagogical programme provided a synthetic way to achieve the objectives set by the educational system at the time thanks to the use of, among others, music and singing [18]. There was also Kodaly's Hungarian system of musical education [19]. Suggestions concerning the use of music in the teaching of motor skills were proposed by Starosta [20], who in his studies provided additional information in the form of an acoustic signal, e.g. sound combined with a command. This kind of simultaneous information could facilitate the acquisition of kinaesthetic sensations. Costa-Giomi [21] analysed the impact of piano playing on the cognitive sphere in children, concluding that their cognitive abilities were improved. The 
literature on the subject also contains examples of methods to achieve cognitive enhancement, referring to this as the so-called Mozart effect [22, 23].

As technology developed and spread, music - increasingly identified with benefits related not only to therapy or physical education - was transferred to competitive sport and recreational physical activity. People started listening to music during track and field training sessions, cycling training sessions or when jogging. It was a matter of time for the impact of music in various disciplines to become a subject of empirical studies. Karageorghis and Terry [24] described the main benefits of listening to music for athletes. These were: a) enhancing a positive and limiting a negative mood; b) arousal before physical activity or relaxation of the body; c) dissociation from unpleasant sensations such as pain and fatigue; d) lowering perceptions of effort; e) enhanced work effectiveness through synchronisation of movement with music; $f$ ) better acquisition of motor skills when adjusting the rhythm to the required movement patterns; g) good mental state; h) increased performance thanks to all the above mechanisms.

Music associated with physical activity, absorbing various sports eventually reached water, responding to the needs of competitive athletes, amateurs and other consumers. Tools enabling swimmers to listen to their favourite music not only before or after but also during a swimming training session enable them to experience the auxiliary functions of music as an ergogenic factor, motivational factor, an element focusing their attention on the task at hand or limiting external information. Given the lack of empirical evidence of beneficial psycho-physical impact of music on swimmers - which has been proven in other disciplines - the present paper attempts to find and confirm such evidence.

\section{Aim of the study}

The main aim of the study was to assess changes in the subjects' motivation levels as a result of providing them with motivational music. The additional aim was to establish differences in swimming effectiveness - expressed in the time needed to cover a distance of $50 \mathrm{~m}$ in a control (C) and an experimental (E) group as a result of providing them with motivational music. The realization of the goal was based on verification of the following research hypothesis: Providing motivational music increases the level of swimmers' motivation and increases swimming effectiveness. To verify the hypothesis the following research questions were put forward: How does the level of motivation change as a result of providing motivational music? and How does the swimming effectiveness change as a result of providing motivational music?

\section{Material and Methods}

\section{Research material}

The subjects were competitive swimmers, $n=8$ swimmers. The small number of research respondents was a result of a pilot character of the study. They were randomly divided into two groups - the control $(C)$ and the experimental $(E)$ one. The subjects' performance level was assessed on the basis of their personal bests over $50 \mathrm{~m}$ front crawl, which were $(\bar{x}=25.58 \pm=2.05)$. The characteristic data of the study subjects (Table 1) reflect the idea behind the choice of the research material, the idea that was subordinated to the aim of the study. The subjects for the study were selected on the basis of the following similarity criteria: a) age; b) mastery of the swimming technique reflected in each swimmer's personal best over $50 \mathrm{~m}$ freestyle. In order to make the groups equal in terms of their performance level, the assumption was that the standard deviation could not be greater than $10 \%$ of the average personal best $(10 \% \bar{x})$ in each group ( $C 10 \% \bar{x}=2.52, \pm=2.48)$, $(E 10 \% \bar{x}=2.60, \pm=1.80)$, a condition that was fulfilled; $c)$ somatic parameters, which became an objective premise testifying to the subjects' similar potential with regard to generating propulsion influencing swimming effectiveness. In order to make the groups equal in terms of this criterion, the assumption was that the standard deviation could not be greater than $10 \%$ of the average body height $(10 \% \bar{x})$ in each group (C 10\% $\bar{x}=18.28, \pm=9.43$ ), $(E 10 \% \bar{x}=17.95, \pm=12.01)$, a condition that was fulfilled. The similarity in somatic parameters and reflected mastery of the swimming technique suggested a similar motor potential of the subjects. 
Table 1. Characteristics of the study groups

\begin{tabular}{|c|c|c|c|c|c|c|}
\hline $\begin{array}{l}\text { 을 } \\
\text { 임 }\end{array}$ & Subjects & $\begin{array}{c}\text { Personal best } \\
50 \mathrm{~m} \text { freestyle } \\
{[\mathrm{s}]}\end{array}$ & $\begin{array}{l}\text { Age } \\
\text { [years] }\end{array}$ & $\begin{array}{l}\text { Height } \\
\text { [cm] }\end{array}$ & $\begin{array}{l}\text { Body weight } \\
\text { [kg] }\end{array}$ & $\begin{array}{c}\left(t_{2,3 / 1}\right) \\
{[\%]}\end{array}$ \\
\hline \multirow{7}{*}{$\begin{array}{l}\text { 을 } \\
\text { 임 }\end{array}$} & $\mathrm{X} 1$ & 28.70 & 23 & 170 & 62.50 & -1.41 \\
\hline & $\mathrm{X} 2$ & 24.60 & 21 & 182 & 74.40 & -3.46 \\
\hline & X3 & 24.50 & 23 & 187 & 82.20 & -0.14 \\
\hline & X4 & 22.90 & 27 & 192 & 91.00 & -0.33 \\
\hline & $\bar{x}$ & 25.80 & 23.50 & 182.75 & 77.52 & \\
\hline & \pm & 2.48 & 2.52 & 9.43 & 12.10 & \\
\hline & $10 \% \bar{x}$ & 2.52 & & 18.28 & & \\
\hline \multirow{7}{*}{ 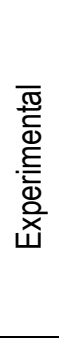 } & Y1 & 28.34 & 22 & 165 & 53.5 & -0.28 \\
\hline & Y2 & 26.36 & 29 & 182 & 80.5 & 0.94 \\
\hline & Y3 & 24.27 & 23 & 177 & 74.1 & 1.16 \\
\hline & Y4 & 24.96 & 23 & 194 & 95.1 & -0.76 \\
\hline & $\bar{x}$ & 25.98 & 24.25 & 179.5 & 75.8 & \\
\hline & \pm & 1.80 & 3.20 & 12.01 & 17.27 & \\
\hline & $10 \% \bar{x}$ & 2.60 & & 17.95 & & \\
\hline \multirow{3}{*}{$\begin{array}{l}\overline{\widetilde{\pi}} \\
\stackrel{0}{\circ}\end{array}$} & $\bar{x}$ & 25.58 & 23.88 & 181.13 & 76.66 & \\
\hline & \pm & 2.05 & 2.70 & 10.14 & 13.83 & \\
\hline & $10 \% \bar{x}$ & 2.56 & & 18.11 & & \\
\hline
\end{tabular}

$\left(\mathrm{t}_{2,311)}\right.$ - assumption that the distance will be covered at $\mathrm{V}$ max.

\section{Research methods}

The method used in the study was that of a laboratory experiment involving two groups $(C$ and E) and an experimental factor (independent variable) for group E. Two measurements - initial (pretest) and final (post-test) - were made accompanied by inter-group comparisons [25]. The study was carried out in a $25 \mathrm{~m}$ indoor swimming pool. The studied parameters were analysed in the Research Laboratory, which has a Quality Management Certificate, ISO 9001:2009. For both study groups - the control $(\mathrm{C})$ and the experimental $(\mathrm{E})$ one - the study consisted in three trials: T1 (pretest), T2, T3 (post-test). The subjects used front crawl technique, starting from a stationary, frontlying position in water. In the first trial (T1) the subjects from both groups swam $50 \mathrm{~m}$ at maximum velocity without received the motivational music (independent variable). In the second and third trial (T2 and T3), the subjects received the independent variable. In these trial the control group (C) performed the trials listening to white noise. The experimental $(E)$ group received motivational music of choice (independent variable). Diagnostic values obtained during the study (motivation level and times over the $50 \mathrm{~m}$ distance) in the control and the experimental group were used to assess the differences between them, as was the impact of music on the subjects' motivation levels and swimming effectiveness. In order to minimise effects of fatigue, the subjects performed all trials with their heart rates at the resting level. The resting heart rates were established before the trials in the 5th minute after a 10-minute warm-up. Each trial took place in water at a unified temperature of $27^{\circ} \mathrm{C}$. The time taken to cover the distance of $50 \mathrm{~m}$ was measured electronically by means of the Colorado Time System with an accuracy of $0.001 \mathrm{~s}$.

\section{Assumption that the distance will be covered at $V$ max}

In order to verify the reliability of task performance (swimming at $\mathrm{V}$ max), an assumption was made that the average time to cover $25 \mathrm{~m}$ in the first trial could not be greater than $10 \%$ of the average time for the distance in the second and third trial (see Table 1), i.e. the average value of swim time for the distance in trials 2 and 3 in relation to the average value of swim time in trial 1 was defined by the following equation (1): 
$t_{2,3 / 1}=100-\frac{t_{2,3}}{t_{1}} \times 100$

\section{Assessed motivation levels}

Before and after the trials the subjects' motivation was assessed. The level of motivation was assessed by means of a motivation questionnaire - MOTO scale [26].

\section{Procedure for preparing the independent variable}

Motivational music meant a musical piece individually selected by a subject and having a motivating function, spurring the subject to perform a specific action or display specific behaviour [27]. Motivation is a system of needs and values defining the direction and degree of an individual's engagement in his or her aspirations and actions [27]. Before the experiment a list of works indicated by the subjects was compiled. The works were then entered into the hard disk of a music playing device. White noise was a type of acoustic noise with a completely flat spectrum.

\section{Research tool}

Sounds were delivered to the subjects by means of a Finis SWIMP3 MP3 player.

\section{Results}

The level of motivation assessed by means of a motivation questionnaire - MOTO scale [26] did not show any changes in the swimmers' motivation.

Statistical analyses were carried out by means of the Statistica 9.0 software. A non-parametric Mann-Whitney $U$ test for two independent trials was used to test statistically significant differences between the studied groups with regard to the times over the $50 \mathrm{~m}$ distance $(\mathrm{C} ; \bar{x}=29.75 \mathrm{~s} ; \pm=$ $3.27),(E ; \bar{x}=29.27 \mathrm{~s} ; \pm=3.08)$. Given the small size of the study group, the Mann-Whitney $U$ test [28] provides no basis to conclude that the experimental group is significantly different from the control group in the analysed variables $(6.00 ; p=0.69)$. This means that the variable used in the study did not influence the times achieved by the swimmers from the experimental group over the $50 \mathrm{~m}$ distance. However, there is a tendency suggesting that we may expect statistical significance with bigger study groups (the small number of subject in this case was associated with the pilot-like nature of the study).

\section{Discussion}

In swimming the role of motivation is regarded as crucial, because after a while monotony may appear among swimmers, especially competitive ones, leading in extreme cases to their abandoning training. As motivational features of music we can consider: a) response to rhythm, b) musicality, c) influence of culture [2, 29]. These qualities of music motivate and help to overcome the invariability of exercises, which, in swimming training, is referred to swimming from wall to wall. The low attractiveness of training itself is discouraging, while training monotony may dampen the enthusiasm of even the most highly motivated swimmers [30]. This is why listening to music during exercises in water has become popular in sport and in leisure activities. Numerous empirical studies have confirmed the beneficial impact of music not only on the psychological but also on the physiological sphere. Szabo, Small and Leigh [6] found that during the switch from slow to fast music the music and its tempo had an ergogenic effect. Szmedra and Bacharach [31] demonstrated that listening to music lowered the heart rate, the lactate level and noradrenalin production when their subjects ran at $70 \% \mathrm{VO}_{2 \max }$. However, not all music produces effects beneficial to the human body during physical activity. When studying the link between the heart rate and musical tempo, Karageorghis, Jones and Low [32] found that fast and moderate tempo influenced the heart rate. Fast tempo of over $120 \mathrm{bpm}$ (beats per minute) is thus preferred during physical activity.

As scientists expanded their knowledge, many experiments began to direct their attention elsewhere as well. The Russian neurologist Alexei Koudinov suspected swimmers listening to music before races of doping $[33,34]$. In sport, ergogenic aids are various substances used by ath- 
letes to enhance their performance [35]. Koudinov's accusations were substantiated by Chou, Wang, Chen and Pai in their studies [36], in which asthma patients undergoing music therapy saw their oxyhaemoglobin - responsible for transporting oxygen from the lungs to the various tissues return to the standard level much faster. The regulations of the World Anti-Doping Agency, WADA, have banned methods improving the transport of oxygen or enhancing its intake or delivery [37]. Thus Koudinov concluded that music was an ergogenic aid. We should also mention here the regulations of the International Swimming Federation, FINA, according to which no swimmer may be allowed to use devices or clothing that could enhance his or her speed, buoyancy or endurance in competition [38]. Due to a lack of available tools that would have made it possible to listen to music when performing exercises in water, it was impossible in the past to determine the impact of music on the performance of various tasks by the swimmers. That is why various experiments concerned physical activities excluding swimming. As technology developed, there appeared commonly available tools that made such analyses possible. It is worth noting that swimming with music during training may have beneficial psychological and physiological effects. It is sufficient to transfer the impact of music we know in other disciplines to swimming and leisure activities in water. In the case of competitive swimming, we should not be too optimistic, because the beneficial effect of music ends at the moment when it is most needed. In their research, Pujol and Lengenfeld [39] did not demonstrate a beneficial effect of music during a Wingate test, which shows that in anaerobic performance at maximum intensity there is no observable beneficial effect of music. On the other hand, Simpson and Karageorghis [40] studied the impact of motivational music during a $400 \mathrm{~m}$ run. Their results show that motivational music lowers the runners' times. This shows that in order to see the expected effects of music in broadly defined physical activity, we cannot forget to take into account such factors as the duration of effort, its intensity, the type of energy transformations used or the number of years in training.

The present paper examines issues related to sport psychology and physiology on the basis of a review of existing research [2, 29, 6,4$]$. It also shows, to a limited degree, that music can be regarded as a support tool in the motor learning process [20], which raises the status of music in broadly defined human physical activity. However, in this study the impact of motivational music on an increase in the swimmers' motivation and swimming effectiveness has not been confirmed.

\section{Conclusions}

In the past extensive research has been conducted to prove motivational advantages of music and its influence on human's psychophysical sphere during motor action. However, in this paper the assumed hypothesis of a positive motivational and ergogenic effect of music on human's psychophysical sphere during swimming was not confirmed. Motivational music did not cause the state of emotional psychophysical stimulation (it was not the ergogenic aid) and did not influence the level of swimmer's motivation. Moreover, it did not contribute to decreased time in swim trials. The results of this experiment point out that music does not have to provide advantages and serve as motivation or ergogenic aid for swimmers in competition-like conditions. However, during monotonous and long-term swimming training music can be a motivational impulse to make effort. It can be assumed that swimming training and recreational forms of physical activity in aquatic environment, unlike competitive swimming, will cause the expression of a motivational function of music.

\section{References}

1. Simon W. Abriss einer Geschichte der Musiktherapie [in German] [An Outline of the History of Music Therapy]. In: G. Harrer, ed. Grundlagen der Musiktherapie und Musikpsychologie. Stuttgart: Fischer; $1975,135-142$.

2. Karageorghis $\mathrm{Cl}$, Terry PC, Lane AM. Development and validation of an instrument to assess the motivational qualities of music in exercise and sport: The Brunel Music Rating Inventory. J Sport Sci 1999, 17:713-724.

3. Karageorghis $\mathrm{Cl}$, Jones $\mathrm{J}$. Effects of synchronous and asynchronous music in cycle ergometry $J$ Sport Sci 2000;18:16. 
4. Hewston R, Lane AM, Karageorghis $\mathrm{Cl}$, Nevill $\mathrm{AM}$. The effectiveness of music as a strategy to regulate mood. J Sport Sci 2005;22:181-182.

5. Tenenbaum G, Lidor R, Lavyan N, et al. The effect of music type on running perseverance and coping with effort sensations. Psychol Sport Exerc 2004;5:89-109.

6. Szabo A, Small A, Leigh M. The effects of slow- and fast-rhythm classical music on progressive cycling to voluntary physical exhaustion. J Sport Med Phys Fit 1999;39:220-225.

7. Tatarkiewicz W. Historia filozofii. Filozofia starożytna i średniowieczna [in Polish] [A History of Philosophy. Ancient and Medieval History]. vol. 1. Warszawa: Wydawnictwo Naukowe PWN; 2003, 65.

8. Maler T. Musik und Ekstate in einer ostafikanischen Medizinmann Praxis [in German] [Music and Ecstasy in East African Medicine Man Practice]. In: Willms H, ed. Musik und Entspannung [Music and Relaxation]. Stuttgart, New York: Fischer; 1977, 29-45.

9. Dotoit CL. Music Movement Therapy. London: The Dalcroze Society (Inc.); 1980, 46.

10. Jaques-Dalcroze E. Rhythm Music \& Education. London: The Dalcroze Society (Inc).; 1980, 36, 64, 91.

11. Kronenberger M. Rytmika: rytm, ruch, muzyka, estetyka, kształcenie, wychowanie, profilaktyka, terapia, taniec, teatr [in Polish] [Eurhythmics: rhythm, movement, music, aesthetics, education, upbringing, prevention, therapy, dance, theatre]. Łódź: Global Enterprises; 2006, 77-82.

12. Janiszewski M. Muzykoterapia aktywna [in Polish] [Active Music Therapy]. Warszawa - Łódź: Akademia Muzyczna w Łodzi - PWN; 1993, 36.

13. Blair D, The Basis of Music Therapy. Br J Music Ther 1983;14(3):2-5.

14. Galińska E. Ocena niektórych aspektów efektywności metody portretu muzycznego na tle analogicznych metod psychoterapii nerwic [in Polish] [An assessment of selected aspects of the effectiveness of the musical portrait method in comparison with analogous methods used in psychotherapy of neuroses]. Psychoterapia 1994;(4):49-60.

15. Strzyżewski S. Proces kształcenia i wychowania w kulturze fizycznej [in Polish] [Education and Upbringing in Physical Culture]. Warszawa: WSiP; 1996.

16. Okoń K. Ruch w rytmie - twórcza metoda gimnastyki rytmicznej M i A Kniesów [in Polish] [Movement in Rhythm - M. and A. Kniees' Creative Method of Rhythmic Gymnastics]. Lider 2002;1:131.

17. Kubinowska D. Edukacja taneczna wg metody Labana [in Polish] [Dance education according to Laban's method]. Kultura Fizyczna 1996;9-10: 29-32.

18. Olszewska I. Praca szkolna K. Orffa w zakresie wychowania przez ruch [in Polish] [C. Orff's School Work and education through movement]. Kultura Fizyczna 1985; 7-8:13-16

19. Tomaszek-Plewa H. Rola muzyki w edukacji i wychowaniu. [in Polish] [The role of music in education and upbringing]. In: Ruch, Muzyka, Taniec. Wrocław; 2001, 77-79.

20. Starosta W. Odświeżanie i budzenie wrażeń kinestetycznych - Nowa metoda doskonalenia techniki sportowej [in Polish] [Refreshment and arousal of kinaesthetic sensations - a new method of improving technique in sport]. Trening 1997;2:41-46.

21. Costa-Giomi E. The effects of three years of piano instruction on children's cognitive development. Journal of Research in Music Education 1999; 47(3):198-212.

22. Pietschnig J, Voracek M, Formann A. Mozart effect-Shmozart effect: A meta-analysis. Intelligence 2010; 38(3):314-323.

23. Rauscher F, Shaw G, Ky C. Music and spatial task performance. Nature 1993;365:611-611.

24. Karageorghis CI, Terry PC. The magic of music in movement. Sport and Medicine Today 2001;5:38-41.

25. Ryguła I. Proces Badawczy w naukach o sporcie [in Polish] [Process Research in the science of sport]. Katowice: AWF, 2003.

26. Widerszal-Bazyl M. Kwestionariusz do mierzenia motywu osiagnięć [in Polish] [A questionnaire for measuring motivation behind achievements]. Przegląd Psychologiczny 1978;21:2.

27. Czajkowski Z. Motywacja w działalności sportowej [in Polish] [Motivation in Sport]. Katowice: Wojewódzka Federacja Sportu; 1987, 4.

28. Corder GW, Foreman DI, Nonparametric Statistics for Non-Statisticians: A Step-by-Step Approach. Wiley: Hoboken (NJ); 2009.

29. North AC, Hargreaves DJ. The musical milieu: Studies of listening in everyday life. The Psychologist 1997; 10:309-312.

30. Rakowski M. Sportowy trening pływacki [in Polish] Competitive Swimming Training. London: M. Rakowski M; 2010, 28-29.

31. Szmedra L, Bacharach DW. Effect of music on perceived exertion, plasma lactate, norepinephrine and cardiovascular hemodynamics during treadmill running. Int J Sport Med 1998; 19:32-37.

32. Karageorghis $\mathrm{Cl}$, Jones L, Low D. Relationship between exercise heart rate and music tempo preference. Res Q Exerc Sport 2006;26:240-250.

33. Koudinov AR. Doping by the pool? The Doping Journal 2004;1(1). 
34. Koudinov AR, Scientific evidence invalidates Beijing 2008 Olympic Swimming medals. The Doping Journal 2008;5(2).

35. Williams M. Granice wspomagania [in Polish] [The limits of enhancement]. Kraków; MedicinaSportiva; $1999,9$.

36. Chou LL, Wang RH, Chen SJ, Pai L. Effects of music therapy on oxygen saturation in premature infants receiving endotracheal suctioning. J Nurs Res 2003;11(3):209-16.

37. The World Anti-Doping code, the 2011 prohibited list international standard, 2011: 6. [on-line at http://www.wada-ama.org/] [accessed March 2012]

38. http://www.fina.org/ FINA Rules 2009 - 2013, point SW 10.8, 10.16. 2009 - 2013, 19-20.

39. Pujol TJ, Langenfeld ME. Influence of music on Wingate anaerobic test performance. Perceptual and Motor Skills 1999;88:292-296.

40. Simpson SD, Karageorghis Cl. The effects of synchronous music on 400-m sprint performance. J Sport Sci 2006;24(10):1095-1102. 